\title{
「血液透析患者の水分管理の自己効力尺度」の開発 一信頼性と妥当性の検討一
}

\author{
榊 みのり ${ }^{1}$ 小 松 浩 子 ${ }^{2}$ \\ 筑波大学大学院人間総合科学研究科看護科学専攻博士前期課程 ${ }^{1}$ \\ 慶應義塾大学大学院健康マネジメント研究科 ${ }^{2}$
}

キーワード：血液透析，水分管理，自己効力，尺度開発，信頼性と妥当性

〈要旨〉

目的：本研究は，血液透析を受ける人々の認知に着目し，個々の生活の場で水分管理を実践することの確信の強 さを測定する質問紙である「血液透析患者の水分管理の自己効力尺度」を開発して, その信頼性と妥当性を検討し, 水分管理という複雑な現象へのケアについて示唆を得ることを目的とした. 方法：尺度を作成する段階において, 血液透析を受ける人々への面接調査から水分管理行動を実行することの確信を表す内容を集め, それらをBandura の自己効力の概念に基づいて分析し，予め，〈水分管理の自己効力>という一元的な構造を設定した. 内容妥 当性や表面妥当性を検討して全 22 項目となった尺度を用い, 外来血液透析患者 220 名を対象として調査を実施し た. 結果 : 分析対象は 209 人であった. 最終的に, 探索的因子分析の結果からも一元的な構造が明らかになった. 尺度の項目数は 15 項目であり，累積寄与率は $55.7 \%$ であった. 本尺度と一般性セルフ・エフィカシー尺度には弱 い正の相関が得られ，また，本尺度と CES-D（全 20 項目，ポジティブ感情を除く 16 項目）には弱い負の相関が得 られたことから，概念的な収束と弁別が支持された．本尺度と 3 か月間の透析間（中 2 日）の体重増加率の平均値 には有意な弱い負の相関が得られ，基準関連妥当性が支持された．本尺度のクロンバック $\alpha$ 值は 0.95 であり，信 頼性が支持された．結論：本尺度は，実用化に向けて，便宜的サンプリング法を用いたことによるバイアスの可能 性や尺度の安定性の検討などの課題を残したが，尺度開発の初期段階としての信頼性と妥当性は支持されたと考え る. 今後の研究ではサンプリング方法を厳密にし, 尺度の対象となる人々にとって回答の負担が少ないように配慮 しながら質問項目をさらに精選し，血液透析を受ける人々の水分管理行動や効果的な支援に関する一層の理解につ なげることが課題である.

\section{The development of fluid management self-efficacy scale for hemodialy- sis patients: A study of the reliability and validity}

Minori Sakaki', and Hiroko Komatsu ${ }^{2}$

Graduate School of Comprehensive Human Sciences Master's Program in Nursing Sciences, University of Tsukuba $^{1}$; Graduate School of Health Management, University of Keio ${ }^{2}$

Key words : hemodialysis, fluid management, self-efficacy, scale development, reliability and validity

〈Abstract〉

Objective : The purpose of this study was to develop a Fluid Management Self-Efficacy Scale for Hemodialysis Patients. Internal consistency, structural validity, and criterion-related validity were tested. Methods : Items were developed to assess self-efficacy in a number of situations associated with difficulty in fluid management. Items were generated from an analysis of interview data in people receiving hemodialysis, and those were analyzed based on the theory of Self-Efficacy of Bandura. A panel of professionals with knowledge of the self-efficacy theory reviewed the first draft of the scale. After face validity, the study was conducted. Data from 220 hemodialysis patients were collected, and 209 subjects were analyzed. Results : A one-factor structure was revealed from the results of exploratory factor analysis. The scale items numbered 15, and the cumulative

\footnotetext{
榊 みのり 筑波大学大学院人間総合科学研究科看護科学専攻博士前期課程

₹ 305-8575 茨城県つくば市天王台 1-1-1
}

Minori Sakaki Tel : 029-853-3403 Fax : 029-853-3403

〔受付日：2012 年 1 月 11 日, 受理日：2012 年 9 月 24 日] 
contribution rate was $55.7 \%$. Structural and criterion-related validities were supported. The Fluid Management Self-Efficacy Scale for Hemodialysis Patients was significantly correlated with the interdialytic weight gain. The high alpha coefficient (0.95) supported the scale as internally reliable. Conclusion : The Fluid Management SelfEfficacy Scale for Hemodialysis Patients was revealed to have satisfactory psychometric properties. The scale may be used in research or in clinical settings to study the mediating effects of self-efficacy or to modify hemodialysis patients' fluid management behavior. Although this first validity study is promising, further validation focusing on reliability and validity is needed.

\section{緒 言}

日本透析医学会の統計報告によると ${ }^{1)}, 2009$ 年度の 国内の透析人口は 290,661 人で年々増加しており，高 齢者や，糖尿病性腎症・腎硬化症等を原疾患とする患 者, 長期治療者の割合が増え, 透析患者の予後の合併 症の発症・増悪の予防が重要視されている，合併症で は例年心不全が上位を占め, 脳血管障害・心筋梗塞を 合わせた心血管障害が透析人口の死因の $36.0 \%$ を占 めている。 それらの一因として, 過剩な水分とナトリ ウムの貯留による体液量依存性高血圧があり, 患者の 水分管理による体重増加の抑制や，適正な除水による 過剩な体内水分とナトリウムの除去により血圧管理を 行うことが重要とされている21.

外来血液透析患者は，週あたり約 $12 \sim 15$ 時間の間 欠的な透析療法を受けているが，その効果は腎臟の生 理的な機能と比較すると限局しているため, 予後の合 併症の発症・増悪の予防には個々の患者における水分 管理の実践の果たす役割が大きい，透析患者が行う水 分管理は，身体の安寧な水分出納バランスを維持する ために, 個人が血圧・体重の測定, 浮腫の観察等によっ て身体状態の変化に気づきながら, 生活の場で水分. 食塩の摂り方を調節することである。

しかしながら，生涯にわたって続く療養行動の実践 に打いて透析患者は日常生活でさまざまなストレスに 直面し, 療養と家庭・社会生活を両立しながら水分・ 食事の制限に取り組むことに強い困難感・負担感を感 じていることが報告されている ${ }^{3-6)}$ ，そのような生活 上の困難と関連して, 透析患者の療養行動の遂行への 支援では，自己効力 ${ }^{7.8)}$ を高めることに焦点を当てた働 きかけの必要性が示唆されている ${ }^{9 \sim 13)}$. 血液透析患者 は，水分管理の自己効力を強くもつことによって，生 活の場でさまざまな困難や障害に直面しても常に必要 なことに注意を向け，積極的に努力を続けて，水分管 理行動を継続して実行できると考える.

透析医療の領域の自己効力に関する研究では, 海外 では, Smith ${ }^{14)}$ が開発した血液透析患者の水分管理の
自己効力尺度を用いた $\mathrm{Brady}^{15)}$ の研究や Lindberg $ら^{16)}$ が開発した Fluid Intake Appraisal Inventory を 用いた研究に扔いて，水分管理の自己効力をより強く もつ透析患者は体重調整がより適切であったことが示 されている．国内では，金ら ${ }^{17}$ による慢性疾患患者の 健康行動に対するセルフ・エフィカシーの尺度や，岡 $ら^{18)}$ による透析患者の食事管理の自己効力尺度, 川端 $ら^{11)}$ による透析管理自己効力感尺度があり，水分管理 を包含した透析自己管理の自己効力を測定するために 使用されている．現在，水分管理の自己効力のみに着 目した尺度は国内にないが，血液透析を受ける人々に おいて，水分管理行動を害行できることによって心血 管疾患の発症・増悪を予防できることを考えると，水 分管理の自己効力をより梁く理解することは重要であ り，それらを客観的に示す尺度が必要である．以上か ら, 本研究は, 血液透析を受ける人々に打ける水分管 理の自己効力を測定するための尺度を作成し，臨床へ の適用をめざして信頼性と妥当性を検証することを目 的とした。

\section{I ．尺度開発のための概念枠組み}

本研究は Bandura の自己効力の概念に基づいて概 念枠組みを規定し，血液透析を受ける人々における生 活の場での水分管理行動を予測するものとして水分管 理の自己効力を位置づけた，血液透析を受けながら水 分管理をしている人々によって知覚される水分管理の 自己効力は，自分の身体の安寧な水分出納バランスを 維持するために水分・塩分の摂り方を調節することが できるという確信である。

\section{II. 方 法}

\section{1．尺度の作成}

1 ）構成概念の検討

自己効力の個人差を測定する尺度の作成に関する先 行研究によると ${ }^{19)}$, Bandura の方法に比較的忠実なの は，ある領域に含まれる課題や状況を数多く集め，回 
答者がその課題や状況での自己効力を評価する項目で 尺度を構成する方法である，それに倣い，血液透析に 通院する慢性腎不全患者 5 名に面接調查を行い，透析 導入時から現在までの水分管理の取り組みについて努 力・忍耐を要する困難な場面を中心に尋ね,「自分は水 分管理をこのようにできる」という考えに関する 75 個の内容を収集した，それらをBandura の自己効力 の概念に基づき解釈し，内容が類似するものを集める ように分類を試みたところ，＜欲求のコントロール＞ <社会的な立場での対応 $><$ 水分出納に関するセル フ・モニタリング $><$ 水分出納のリズムをつくる行 為>という四つの側面に命名できるように思われた. しかし水分管理の自己効力を表す一つ一つの内容につ いて，その前後の文脈を汲むように，語られた全体を 繰り返し読みながら再検討した結果，たとえば「付き 合いの拪酒の席であっても，自分なりに決めた量以上 に飲まない」の内容は＜社会的な立場での対応 $><$ 欲 求のコントロール>のどちらにも分類され得るという ように，一面的に見ることができない多重の面から成 り立つものが多く, 明確に分類できなかった. よって, 水分管理の自己効力の内容を構成するのは<水分管理 の自己効力>という一つの内容であると捉えた.

2) 項目作成と選定

前述の構成概念に基づき，外来血液透析患者の面接 調查で収集した内容と, 既存の尺度11,14,17.18), 手記20 23) から収集した内容を精選して 38 項目を作成した。次 に内容妥当性の検討として, 概念の定義と質問項目と の合致度に関して専門家（透析看護の経験が豊富な看 護師 3 名と透析看護の研究に携わる研究生 2 名）に尋 ね,「あまり合致していない」,「ほとんど合致していな い」と判定した人の割合が $80.0 \%$ 以上の 4 項目を削除 し, 一部の表現を修正して 26 項目の尺度案を作成し た.

続いて, 質問項目の回答のしやすさ・理解しやすさ・ 心理的な負担に関して, 血液透析に通院する慢性腎不 全患者 10 名を対象に調査した。結果に基づいて回答 しにくい項目を削除・修正し，最終的に血液透析患者 の水分管理の自己効力尺度（以下，本尺度と略す）は 表 1 に示すように全 22 項目となった.

本尺度の各項目の選択肢は, Banduraが「必要な活 動を実行するための能力における信念の強さを評価す るため, 意図の言明である “will do”ではなく, 能力の 判断である “can do” で表現する」と述べていること から ${ }^{7)}$, 語尾に「できる」を用い, どの位の頻度で実行 できるかを問うのではなく，どの位確実に実行できる かを問うため,「1. まったくできない」から「4. ほと
表 1 「血液透析患者の水分管理の自己効力尺度」

(22 項目)

\begin{tabular}{|c|c|}
\hline No & 項目内容 \\
\hline 1 & $\begin{array}{l}\text { 体重が増えすぎたと思ったら，翌日の水分を少なくして， } \\
\text { 体重の調節できる }\end{array}$ \\
\hline 2 & $\begin{array}{l}\text { 水分を多くとると自分の体の調子がどう変わるかを予測で } \\
\text { きる }\end{array}$ \\
\hline 3 & 自分の日頃の血圧の変化に気づくことができる \\
\hline 4 & 自分がどんな時に塩分を多くとりやすいかを特定できる \\
\hline 5 & $\begin{array}{l}\text { 体調がいいと感じている時でも, 気がゆるんで水分をとり } \\
\text { すぎないように調節できる }\end{array}$ \\
\hline 6 & $\begin{array}{l}\text { 体重計で増えを確認しながら, 水分のとり方を調節するこ } \\
\text { とができる }\end{array}$ \\
\hline 7 & お酒を飲むとき, 自分で決めた量で飲むのをやめられる \\
\hline 8 & $\begin{array}{l}\text { 自分の体調を知らない人にすすめられた時でも, 塩分の多 } \\
\text { い食品は食べすぎないようにすることができる }\end{array}$ \\
\hline 9 & 宴会や食事会に行く時でも，体重の増えを調節できる \\
\hline 10 & $\begin{array}{l}\text { 夏から秋にかけて汗の量が減る時期でも，体重が増えすぎ } \\
\text { ないように調節できる }\end{array}$ \\
\hline 11 & $\begin{array}{l}\text { 自分の好物でも，塩分の多い食品は食べすぎないようにす } \\
\text { るとができる }\end{array}$ \\
\hline 12 & $\begin{array}{l}\text { 週末などで, 透析と透析の間が } 2 \text { 日以上あく時でも，自分 } \\
\text { の体重増加量を決めて，それ以上に増えないように調節で } \\
\text { きる }\end{array}$ \\
\hline 13 & $\begin{array}{l}\text { 自分の心胸比（心臟の大きさ）の変化に気づくことができ } \\
\text { る }\end{array}$ \\
\hline 14 & $\begin{array}{l}\text { 塩分の多い食品を食べると水分がほしくなることが予測で } \\
\text { きる }\end{array}$ \\
\hline 15 & $\begin{array}{l}\text { 食べた後, のどが渇いた食品は, 次から量を減らすか食べ } \\
\text { るのをやることがきる }\end{array}$ \\
\hline 16 & $\begin{array}{l}\text { 熱いお茶をすこし飲むようにするなど，効果的にのどをう } \\
\text { るおす土ができる }\end{array}$ \\
\hline 17 & $\begin{array}{l}\text { 塩分を少なくして，のどが渇いて飲みすぎるのを防ぐこと } \\
\text { ができる }\end{array}$ \\
\hline 18 & $\begin{array}{l}\text { 除水量（体から水をひく量）が多いと自分の体にどんな症 } \\
\text { 状がでるか予測できる }\end{array}$ \\
\hline 19 & $\begin{array}{l}\text { 外出した時でも, 水分をとりすぎないようにすることがで } \\
\text { きる }\end{array}$ \\
\hline 20 & 外食のとき, 塩分を感じる食物は残すなどの調節ができる \\
\hline 21 & 食事のとき, 塩分の多い調味料を少なく使う工夫ができる \\
\hline 22 & $\begin{array}{l}\text { 家で過ごす時でも，食事以外の不規則な時間に，お茶や氷 } \\
\text { をとりすきいうこする゙できる }\end{array}$ \\
\hline
\end{tabular}

んどできる」とし, 得点はそれぞれ 1 点〜 4 点とした また, 血液透析患者の水分管理の個別性を考慮し,「0. あてはまらない」を設定した，本尺度の評価方法は， 全項目の合計得点を算出し, 得点が高いほど自己効力 が強いことを表すとした。

\section{2. 信頼性と妥当性の検討}

\section{1) 対 象}

調查協力の得られた千葉県の 2 箇所の透析施設にお いて, 慢性腎不全にて週 3 回の血液透析を受けている 外来患者 220 名を対象とした，a）調查目的・方法を説 明し, 承諾の得られた人, b) 質問紙の内容を理解し 
表 2 対象者の背景

\begin{tabular}{|c|c|c|c|}
\hline 年齢（歳） & $57.37 \pm 10.02$ & 最小值 30, & 最大值 83 \\
\hline \multirow[t]{2}{*}{ 性別 } & 男性 & 126 & $(60.3 \%)$ \\
\hline & 女性 & 83 & $(39.7 \%)$ \\
\hline 血液透析歴 (年) & $10.2 \pm 7.87$ & 最小值 0.5, & 最大值 31 \\
\hline \multirow[t]{5}{*}{ 原疾患 } & 慢性糸球体腎炎 & 110 & $(52.6 \%)$ \\
\hline & 糖尿病性腎症 & 25 & $(12.0 \%)$ \\
\hline & 腎硬化症 & 10 & $(4.8 \%)$ \\
\hline & 囊胞腎 & 6 & $(2.9 \%)$ \\
\hline & 他 & 58 & $(27.8 \%)$ \\
\hline \multirow[t]{2}{*}{ 糖尿病 } & なし & 184 & $(88.0 \%)$ \\
\hline & あり & 25 & $(12.0 \%)$ \\
\hline $\begin{array}{l}\text { 透析間中 } 2 \text { 日の } \\
\text { 体重増加率 (\%) }\end{array}$ & $4.70 \pm 1.4$ & 最小值 0.06, & 最大值 9.50 \\
\hline \multirow[t]{6}{*}{ 就労状況 } & 主婦 & 54 & $(26.0 \%)$ \\
\hline & 正規 & 43 & $(20.7 \%)$ \\
\hline & 自営業 & 25 & $(12.0 \%)$ \\
\hline & パート & 12 & $(5.8 \%)$ \\
\hline & 正規・パート以外 & 11 & $(5.3 \%)$ \\
\hline & 無職 & 63 & $(30.3 \%)$ \\
\hline \multirow[t]{2}{*}{ 配偶者 } & あり & 147 & $(72.8 \%)$ \\
\hline & なし & 55 & $(27.2 \%)$ \\
\hline \multirow[t]{2}{*}{ 同居家族 } & あり & 138 & $(74.6 \%)$ \\
\hline & なし & 47 & $(25.4 \%)$ \\
\hline \multirow[t]{4}{*}{ 調理の担当 } & 家族 & 97 & $(49.7 \%)$ \\
\hline & 本人 & 83 & $(42.6 \%)$ \\
\hline & 本人と家族が分担 & 12 & $(6.2 \%)$ \\
\hline & 他 & 3 & $(1.5 \%)$ \\
\hline \multirow[t]{2}{*}{ 飲酒の有無 } & あり & 78 & $(38.0 \%)$ \\
\hline & なし & 127 & $(60.8 \%)$ \\
\hline
\end{tabular}

て，自己記入または聞き取り式にて回答できる人，c） 超高齢者, 重度の心血管合併症・感染症などを有する 人，不安や抑うつなどで精神的な治療を要する人，現 状に対して心理的に不安的な状態にある人を除く, d) 透析導入後 1 か月未満の人を除くとした. 対象者は便 宜的サンプリング法で抽出した。

2) デー夕収集

デー夕収集期間は平成 14 年 9 月〜 11 月で，研究者 自身が透析時間中に質問紙を直接手渡しし，回答後は 無記名の封筒に入れてもらい, その場で回収した。

\section{3 ）倫理的配慮}

本研究の対象者の選定は, 透析治療医師と透析室師 長によって調査への参加が可能であると判断した人を 対象とし, 専門家が病状や心理状態が不安定であると 判断した人を対象としないことを配慮した。また，調 査にあたりプライバシーの保護に重点をおき，倫理的 な配慮を心がけた。本研究は平成 14 年度第 3 回聖路 加看護大学研究倫理審査委員会の承認を得て実施し た。

\section{4) 分析方法}

構成概念妥当性は，探索的因子分析として主因子法 と最尤法を行い，尺度の作成段階で予め設定していた 概念の構造との一致について確認した。因子軸の回転 は因子間に相関関係があると予測されたためプロマッ クス回転を用い, 因子数はスクリー基準を組み合わせ て固有值, 累積寄与率, 信頼性係数などを検討しなが ら設定した。

概念的な収束 - 弁別は, 本尺度と一般性自己効力, 抑うつとの関係について検討した. 本尺度の自己効力 が血液透析を受ける人々における水分管理を実行する ことの確信という課題固有的であるのに対し，一般性 自己効力は特定の課題を越えて一般的な統制感を形成 するものである ${ }^{19)}$ 。一般性自己効力の測定は，信頼 性・妥当性が確認されている一般性セルフ・エフィカ シー尺度（general self-efficacy scale ; 以下, GSES と 略す）を用いた ${ }^{24,25)}$ 。収束については, 本尺度と GSES は, 自己効力という同じ構成概念をもつため, 双方の 尺度の得点は正の相関があると考えられる．弁別につ いては，一般性自己効力が高くても課題固有的な自己 効力が低いためにその課題に関する行動を実行しない 場合があると推測されるため, 課題固有的な自己効力 を測定する尺度の本尺度の得点と一般性自己効力を測 定する尺度の GSES の得点間の相関は高くないと考 えられる。これらから双方の尺度の得点の間には弱い 正の相関があると考えられた．次に，自己効力と抑う つの関係から構成概念妥当性を検討した. Bandura によると, 自己効力が低いことは务威や困難な状況で 不安や抑うつをどの程度に体験するかに影響し，自己 効力が低く潜在的な勗威をコントロールできないと確 信する人は潜在的な劦威を実際より強く捉え, 対処す る力を欠いたまま徐々に自身で機能を低めるといわれ $ろ^{26)}$. 抑うつの測定には信頼性・妥当性が確認されて いる CES-D を用いた ${ }^{27)}$ 。また下位尺度に関して，ポ ジティブ感情は一般的なうつ症状や個別のうつ症状を 構成する症状に対して独立していると指摘されている ため ${ }^{28)}$, 本研究では, CES-D の全 20 項目と, ポジティ ブ感情を除く 16 項目の両方において，本尺度との相 関を検討した，収束については，自己効力が低いと抑 うつが強くなるという関係が理論的に示されているこ とから ${ }^{8)}$, 本尺度と CES-D の尺度の得点は負の相関 があると考えられる。弁別については, 本尺度と CES-D は異なる構成概念を持つことから双方の尺度 の得点間の相関は高くないと考えられる. 以上から, 双方の尺度の得点の間には弱い負の相関があると考え られた。 
表 3 「血液透析患者の水分管理の自己効力尺度」の因子分析（18 項目）

固有值 1 以上の設定

【因子抽出法：主因子法, 回転法：Kaiser の正規化を伴うプロマックス法】

$\mathrm{n}=209$

\begin{tabular}{|c|c|c|c|c|c|c|}
\hline \multirow{2}{*}{ 因子 } & \multirow{2}{*}{$\begin{array}{l}\text { 項目 } \\
\text { 番号 }\end{array}$} & \multirow{2}{*}{ 項目 } & \multirow{2}{*}{ 第 1 因子 } & \multirow{2}{*}{ 第 2 因子 } & \multirow{2}{*}{ 第 3 因子 } & 共通性 \\
\hline & & & & & & 因子抽出後 \\
\hline \multirow{8}{*}{$\begin{array}{l}\text { 水分を調節 } \\
\text { できる }\end{array}$} & 1 & $\begin{array}{l}\text { 体重が増えすぎたと思ったら, 翌日の水分を } \\
\text { 少なくして, 体重の増えを調節できる }\end{array}$ & 0.961 & -0.279 & & 0.641 \\
\hline & 5 & $\begin{array}{l}\text { 体調がいいと感じている時でも, 気がゆるん } \\
\text { で水分をとりすぎないように調節できる }\end{array}$ & 0.792 & & & 0.603 \\
\hline & 6 & $\begin{array}{l}\text { 体重計で増えを確認しながら, 水分のとり方 } \\
\text { を調節することができる }\end{array}$ & 0.743 & -0.114 & 0.177 & 0.615 \\
\hline & 12 & $\begin{array}{l}\text { 週末などで, 透析と透析の間が } 2 \text { 日以上あく } \\
\text { 時でも，自分の体重増加量を決めて，それ以 } \\
\text { 上に増えないように調節できる }\end{array}$ & 0.687 & & 0.112 & 0.680 \\
\hline & 22 & $\begin{array}{l}\text { 家で過ごす時でも，食事以外の不規則な時間 } \\
\text { に，お茶や氷をとりすぎないようにすること } \\
\text { ができる }\end{array}$ & 0.682 & 0.344 & -0.200 & 0.712 \\
\hline & 10 & $\begin{array}{l}\text { 夏から秋にかけて汗の量が減る時期でも, 体 } \\
\text { 重が増えすぎないように調節できる }\end{array}$ & 0.659 & & 0.109 & 0.634 \\
\hline & 9 & $\begin{array}{l}\text { 宴会や食事会に行く時でも, 体重の増えを調 } \\
\text { 節できる }\end{array}$ & 0.573 & 0.271 & & 0.592 \\
\hline & 19 & $\begin{array}{l}\text { 外出した時でも，水分をとりすぎないように } \\
\text { することができる }\end{array}$ & 0.536 & 0.315 & & 0.663 \\
\hline \multirow{7}{*}{$\begin{array}{l}\text { 塩分を調節 } \\
\text { できる }\end{array}$} & 11 & $\begin{array}{l}\text { 自分の好物でも, 塩分の多い食品は食べすぎ } \\
\text { ないようにすることができる }\end{array}$ & & 0.889 & & 0.650 \\
\hline & 8 & $\begin{array}{l}\text { 自分の体調を知らない人にすすめられた時で } \\
\text { も, 塩分の多い食品は食べすぎないようにす } \\
\text { ることができる }\end{array}$ & & 0.815 & & 0.530 \\
\hline & 15 & $\begin{array}{l}\text { 食べた後, のどが渇いた食品は, 次から量を } \\
\text { 減らすか食べるのをやめることができる }\end{array}$ & -0.211 & 0.772 & 0.239 & 0.621 \\
\hline & 17 & $\begin{array}{l}\text { 塩分を少なくして，のどが渇いて飲みすぎる } \\
\text { のを防ぐことができる }\end{array}$ & 0.282 & 0.572 & & 0.684 \\
\hline & 20 & $\begin{array}{l}\text { 外食のとき, 塩分を感じる食物は残すなどの } \\
\text { 調節ができる }\end{array}$ & 0.152 & 0.597 & & 0.588 \\
\hline & 21 & $\begin{array}{l}\text { 食事のとき，塩分の多い調味料を少なく使う } \\
\text { 工夫ができる }\end{array}$ & 0.282 & 0.487 & & 0.556 \\
\hline & 16 & $\begin{array}{l}\text { 熱いお茶をすこし飲むようにするなど, 効果 } \\
\text { 的にのどをうるおす土夫ができる }\end{array}$ & 0.246 & 0.403 & 0.207 & 0.588 \\
\hline \multirow{3}{*}{$\begin{array}{l}\text { 潜在的なリスク } \\
\text { を予測できる }\end{array}$} & 3 & $\begin{array}{l}\text { 自分の日頃の血圧の変化に気づくことができ } \\
\text { る }\end{array}$ & & & 0.652 & 0.416 \\
\hline & 4 & $\begin{array}{l}\text { 自分がどんな時に塩分を多くとりやすいかを } \\
\text { 特定できる }\end{array}$ & 0.103 & & 0.584 & 0.417 \\
\hline & 13 & $\begin{array}{l}\text { 自分の心胸比 (心臓の大きさ) の変化に気づ } \\
\text { くことができる }\end{array}$ & & 0.134 & 0.481 & 0.336 \\
\hline & & $\begin{array}{ll} & \text { 回転後の負荷量平方和 } \\
& \text { 回転前の累積寄与率 }\end{array}$ & $\begin{array}{l}8.25 \\
50.8 \%\end{array}$ & $\begin{array}{l}7.84 \\
55.3 \%\end{array}$ & $\begin{array}{l}5.50 \\
58.3 \%\end{array}$ & \\
\hline
\end{tabular}

基準関連妥当性は，本尺度と透析間の体重増加率の 平均值との関連を検討した。体重増加率は，前回の透 析後から次の透析前にかけての体重増加量をドライ ウエイトで割って算出する值である. Brady ${ }^{15)}$ の先 行研究に基づき, 透析の治療日と治療日の間が 2 日間 あく週末の体重増加率の 3 か月間の平均值を算出し た. 水分管理の自己効力を強くもつ患者は, 透析間が
中 2 日あいても体重増加率を適切な範囲内に調整でき ると考えた。

信頼性は, 内部一貫性を検証し, クロンバック $\alpha$ 值 （ $\alpha$ 係数と略す）を算出した. 得られたデータの分析 には統計パッケージ SPSS Ver. 11 Windows 版を用い た。 
表 4 「血液透析患者の水分管理の自己効力尺度」の因子分析（15 項目）

因子数の設定 : 1

【因子抽出法：主因子法】

\begin{tabular}{|c|c|c|c|c|}
\hline \multirow{2}{*}{ 因子名 } & \multirow{2}{*}{ 項目番号 } & \multirow{2}{*}{ 項目 } & \multirow{2}{*}{ 因子負荷量 } & 共通性 \\
\hline & & & & 因子抽出後 \\
\hline \multirow{15}{*}{$\begin{array}{l}\text { 水分管理の } \\
\text { 自己効力 }\end{array}$} & 17 & $\begin{array}{l}\text { 塩分を少なくしで，のどが渇いて飲みすぎるのを } \\
\text { 防ぐことができる }\end{array}$ & 0.821 & 0.674 \\
\hline & 22 & $\begin{array}{l}\text { 家で過ごす時でも，食事以外の不規則な時間に, } \\
\text { お荼や氷をとりすぎないようにすることができる }\end{array}$ & 0.820 & 0.672 \\
\hline & 19 & $\begin{array}{l}\text { 外出した時でも, 水分をとりすぎないようにする } \\
\text { ことができる }\end{array}$ & 0.815 & 0.665 \\
\hline & 12 & $\begin{array}{l}\text { 週末などで, 透析と透析の間が } 2 \text { 日以上あく時で } \\
\text { も, 自分の体重増加量を決めて, それ以上に増え } \\
\text { ないように調節できる }\end{array}$ & 0.802 & 0.644 \\
\hline & 10 & $\begin{array}{l}\text { 夏から秋にかけて汗の量が減る時期でも, 体重が } \\
\text { 增えすぎないよう調節できる }\end{array}$ & 0.775 & 0.600 \\
\hline & 16 & $\begin{array}{l}\text { 熱いお茶をすこし飲むようにするすなど，効果的に } \\
\text { のどをうるおす拈できる }\end{array}$ & 0.753 & 0.567 \\
\hline & 9 & $\begin{array}{l}\text { 宴会や食事会に行く時でも, 体重の増えを調節で } \\
\text { きる }\end{array}$ & 0.764 & 0.584 \\
\hline & 21 & $\begin{array}{l}\text { 食事のとき, 塩分の多い調味料を少なく使う工夫 } \\
\text { ができる }\end{array}$ & 0.742 & 0.550 \\
\hline & 5 & $\begin{array}{l}\text { 体調がいいと感じている時でも, 気がゆるんで水 } \\
\text { 分をとりすぎないうに調節できる }\end{array}$ & 0.734 & 0.539 \\
\hline & 20 & $\begin{array}{l}\text { 外食のとき, 塩分を感じる食物は残すなどの調節 } \\
\text { ができる }\end{array}$ & 0.724 & 0.524 \\
\hline & 6 & $\begin{array}{l}\text { 体重計で増えを確認しながら, 水分のとり方を調 } \\
\text { 節することがぎ゙る }\end{array}$ & 0.722 & 0.522 \\
\hline & 11 & $\begin{array}{l}\text { 自分の好物でも, 塩分の多い食品は食べすぎない } \\
\text { ようにすることができる }\end{array}$ & 0.706 & 0.498 \\
\hline & 1 & $\begin{array}{l}\text { 体重が増えすぎたと思ったら，翌日の水分を少な } \\
\text { くして，体重の増えを調節できる }\end{array}$ & 0.677 & 0.459 \\
\hline & 15 & $\begin{array}{l}\text { 食べたあとのどが渇いた食品は, 次から量を減ら } \\
\text { すか食べるのをや゙でるる }\end{array}$ & 0.672 & 0.452 \\
\hline & 8 & $\begin{array}{l}\text { 自分の体調を知らない人にすすめられた時でも, } \\
\text { 塩分の多い食品は食べすぎないようにすることが } \\
\text { できる }\end{array}$ & 0.637 & 0.406 \\
\hline
\end{tabular}

\section{III. 結 果}

\section{1. 対象者の背景（表 2)}

有効回答者 209 名（有効回答率 $84.2 \%$ ）を分析対象 とした，透析間の中 2 日の体重増加率は, 最小值 $0.06 \%$ から最大值 $9.50 \%$ の範囲で，平均值は $4.70 \%$ であった。

\section{2. 基本統計量}

本尺度の合計得点の平均值は, 22〜 88 点を取り得る 中で 63.14 点 (SD10.78) であり, 各項目の平均值は 1〜4 点を取り得る中で $2.60 〜 3.40$ の範囲であった.

3. 構成概念妥当性（表 3, 表 4）

$\mathrm{I}$ 一 $\mathrm{T}$ 相関を算出したところ, 0.7 以上の項目として
No. 10 と No. 12 (相関係数 0.711 ) 認めたが, 内容面 で異なると判断し，削除せず分析に加えた，次に，回 答に強い偏りを認めた項目を検討し，No.7 は全対象 者において無回答および選択肢の「あてはまらない」 の回答を足すと $45.0 \%$ に至り, 飲酒ありの群において 選択肢の「ほとんどできる」と「まあまあできる」の 回答を合わせると $94.8 \%$ に偏っていたため, 回答を振 り分ける機能を持たない項目と判断し, 以降の分析か ら除外した. 同様にNo.2，14，18も「ほとんどでき る」と「まあまあできる」の回答を足すと $90.0 \%$ 以上 に偏っていたことから不適切な項目として除外した。 以上の結果, 18 項目で因子分析を行った.

スクリープロットでは第 2 因子を境になだらかに なっていた．始めに因子数を 3 に設定した分析結果 
表 5 「血液透析患者の水分管理の自己効力尺度」の妥当 性の検討

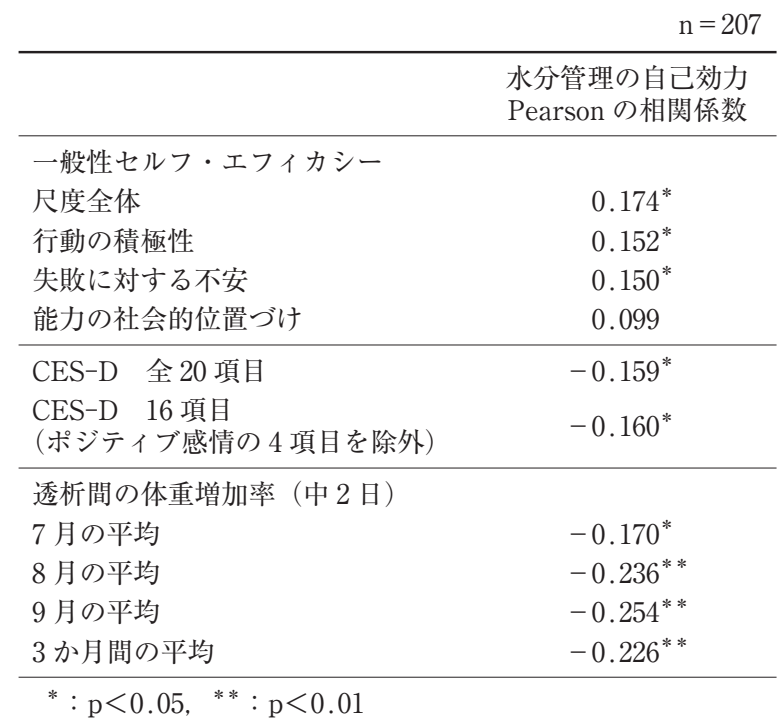

は，表 3 に示すように<水分を調節できる>，＜塩分 を調節できる〉，〈潜在的なリスクを予測できる>と いう解釈ができると思われた。しかし，3因子を尺度 化した場合の信頼性倸数では＜水分を調節できる>は 0.927，＜塩分を調節できる>は 0.909 と高いことに 比べ，〈潜在的なリスクを予測できる>は 0.642 と低 かった．さらに，3因子それぞれと透析間の体重増加 率との関連を調べたところ, Pearsonの相関の検討結 果にて<水分を調節できる>は $\mathrm{r}=-0.229(\mathrm{p}=$ 0.001)，＜塩分を調節できる>は $\mathrm{r}=-0.193(\mathrm{p}=$ 0.005)であり, 双方が体重増加率との有意な相関を認 めたが，〈潜在的なりスクを予測できる>は相関を認 めなかった，よって，＜潜在的なリスクを予測でき る>に含まれた No. 3, No.4, No.13 は体重増加率と 関連しなかったため削除した。「No.16 熱い打茶を 少し飲むようにするなど，効果的にのどをうる打す工 夫ができる」は＼cjkstart塩分を調節できる>に分類され，他 項目と内容が異なっていたが, 体重増加率との有意な 関連 $\mathrm{r}=-0.206 （ \mathrm{p}=0.003 ）$ を認めたため, 削除も適 切ではないと考えられた．次に，上記 3 項目を除いた 15 項目にて因子数を 2 に設定して分析したところ, ＜水分を調節できる >と＜塩分を調節できる>という 解釈ができるように思われた，前述の No. 16 は因子 負荷量が 0.4 以下で低かった。 また，＜水分を調節で きる>に含まれた「No.9 宴会や食事会に行く時で も，体重の増えを調節できる」と「No.10 夏から秋に かけて汗の量が減る時期でも，体重が増えすぎないよ うに調節できる」の項目は, 内容を検討したところ

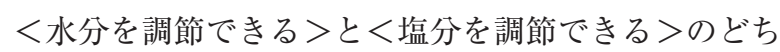

らかへ分類することはできないと考えられた。これら の項目は体重増加率との有意な関連を認めたため, 削 除も適切ではないと考えられた，そこでNo.16 を除 き，〈水分を調節できる>と＜塩分を調節できる>と の類似性を検討したところ，2 因子間の相関は 0.763 と高かった。 また， 2 因子と GSES, CES-D との Pearsonの相関を比較すると，〈水分を調節できる> と GSES $(r=0.143, \mathrm{p}<0.005), C E S-D$ 全 20 項目 $(-0.157, \mathrm{p}<0.005),<$ 塩分を調節できる $>$ GSES $(\mathrm{r}=0.183, \mathrm{p}=0.001), \mathrm{CES}-\mathrm{D}$ 全 20 項目 $(\mathrm{r}=-0.155$, $\mathrm{p}<0.005)$ のように著明な差異がなかった。 そのた め, <水分を調節できる $>$ と塩分を調節できる>は, <水分管理の自己効力 $>$ いう一つの因子であると考 えられた．水分の調節と塩分の調節は対象者によって 同時に行われるものであり，二つの内容を一つのまと まりとして解釈する方が適切であると考元, 因子数を 1 に設定して因子分析を行ったところ, 表 4 に示すよ うに 15 項目のすべてが因子負荷量 0.6 以上の值で一 つの因子に揃い，一元的な構造であることが明らかに なった. 15 項目となった本尺度の基本統計量は, 尺度 の合計得点が 15 60 点を取り得る中で, 平均值は 44.58 点（SD8.36）であり, 対象者の合計得点の分布 では偏りを認めなかった。

\section{4. 構成概念妥当性（概念的な収束·弁別）（表 5）}

本尺度と GSES との間に有意な弱い正の相関を認 めたことから，本尺度と GSESについて概念的な収束 と弁別が支持されたと判断した. 次に, 本尺度と CES-D の全 20 項目との間, CES-D 全体からポジティ ブ感情の項目を除く 16 項目との間の双方に有意な弱 い負の相関を認めた。 よって, 本尺度と CES-D につ いて概念的な収束と弁別が支持されたと判断した。

\section{5. 基準関連妥当性（予測妥当性）（表 5）}

本尺度の合計得点と, 透析間の体重増加率との関連 を検討した結果, 表 5 に示すように全体として有意な 弱い負の相関を認めた，一方, GSES と透析間の体重 増加率には有意な関連を認めなかった。

\section{6. 信頼性}

信頼性係数は, 0.70 以上の值を示せば安定度は高い とされる ${ }^{29)}$. 本尺度の $\alpha$ 係数は 0.95 であった。

\section{IV. 考 察}

\section{1. 対象者の特徵}

本研究の対象者は, 本尺度の合計得点が 15 60 点 の範囲を取り得る中で, 平均得点が 44.58 点 (SD8.36) と高かった。 得点の高さに影響を与えた要因として, 
平均年齢において, 日本透析医学会の統計報告（平成 12 年度 ${ }^{30)}$ の 61.2 歳に対し, 本研究の対象者は 57.4 歳（SD10.02）と若かったことと, 透析年数に関して, 学会報告にて透析年数 15 年以上の群が占める割合が 全体の $12.0 \%$ であるのに対し, 本研究の対象者は全体 の $31.0 \%$ を透析年数 15 年以上の群が占め, 長期透析 者の割合が高かったことが考えられた。また自己効力 を高める四つの情報源の一つとして，個人が自分の生 理学的状態の安定を認識することにより自己効力を高 められることから ${ }^{8)}$, 本研究は, 対象の選定基準とし て重篤な身体状態や不安定な精神状態にある人を除い たため，対象者には自分の体調の安定を自覚している 人が多かったと推測され，そのことも得点に影響した と考えられた。

\section{2. 本尺度の妥当性}

探索的因子分析の検討にて，〈水分管理の自己効 カ>という 1 因子の構造を認めたが, これは本尺度の 作成段階に抒いて，血液透析を受ける人々への面接調 查で集めた水分管理の自己効力の内容について Bandura の自己効力の概念に基づいて分析し，予め設定 した構造と矛盾していなかった．概念的な収束と弁別 では, 本尺度と GSES, CES-D との関係から検討した 結果から，概念的な収束と并別が概ね支持された，基 準関連妥当性は, 本尺度と体重増加率の関連を検討し た結果から支持されたが課題も示された．実際の水分 管理では，必要な栄養を摂りながら水分を適度に抑え ることが非常に難しく，そのため透析患者の中には食 事量を軽くすることで体重増減の調節を図り，身体の 水分出納バランスを崩して溢水を招くという問題が生 じやすい。したがって，そのような体重增減のみに着 目した調節を識別するため, 本尺度と水分摂取量の自 己記録, BMI 指数, アルブミン血中濃度などの生理学 的指標との関連について検討する必要があると考えら れた。

\section{3．本尺度の信頼性}

本尺度は, 開発段階の尺度としては高い内部一貫性 が確保されたといえる．しかし項目間の相関係数が高 い項目を多く揃えることにより $\alpha$ 係数の值が高くな

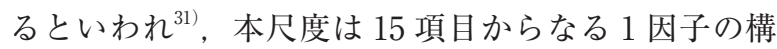
造であることから $\alpha$ 係数が高められている可能性が ある．よって，今後はより少ない項目数で高い信頼性 係数を確保するように検討することが課題である.

\section{4. 本研究の限界}

本研究は便宜的サンプリング法を用いたため, 対象 者の背景によって回答の傾向が影響を受けた可能性が ある．今後の研究ではサンプリング方法を検討し，多
様な背景の対象者において尺度の信頼性や安定性を確 認する必要がある.

また，本尺度の項目は，実際に血液透析を受けなが ら水分管理をしている方々から水分管理の取り組みに 努力・忍耐を要するような困難な場面を中心に伺い,

「自分は, 水分管理をこのようにできる」という個人の 考えに関する内容を収集して作成した，その際，対象 となる方々に共通する課題を含むように水分・塩分の 摂り方の調節が困難である代表的な状況を選定した結 果, 岡 ${ }^{18)}$ や川端ら ${ }^{11)}$ の自己効力尺度の項目の状況と 一部類似したため, 本尺度の項目 No. 8, 9, 11，12，19 について，それらの尺度との併存妥当性を検証する必 要がある. 今後, 尺度の対象となりうる人々にとって 回答の負担が少ないように配慮しながら尺度の有用性 を高めるための研究を重ね, 質問項目を精選していく ことが課題である.

これらの限界があるが, 本尺度は, 血液透析を受け る人々に打ける水分管理という複雑な現象の共通理解 を深めることをめざして作成した, 水分・塩分の摂り 方を調節するという視点を含む自己効力尺度として国 内では唯一のものである. 外来透析の臨床において, 透析間の体重増加率などの生理学的指標と併用させな がら，血液透析を受ける人々の生活の場の水分管理行 動を予測するアセスメントッールとして活用できると 考える．また，血液透析を受ける人々にとってこの尺 度を活用することは，水分管理の実践をふり返り，以 前と比べて改善した行動について再認識する機会とな り, より良い水分管理に向けて, 自分の潜在能力をさ らに発揮することにつながると考える。

\section{結論}

血液透析患者に打ける水分管理を実行することの確 信の強さを測定する尺度として作成した「血液透析患 者の水分管理の自己効力尺度」は，15 項目からなる 5 段階評価の質問紙となった。本尺度はく水分管理の自 己効力 >という一つの構成要素からなり, 概念的な収 束と弁別は概ね支持された。 基準関連妥当性は, 予測 妥当性について検証して支持された。信頼性係数は十 分な值を示し，信頼性が確保された，本尺度は，尺度 開発の初期段階としての信頼性と妥当性は概ね検証で きた．今後は，血液透析を受ける人々の水分管理行動 や効果的な支援に関する一層の理解をめざして, 信頼 性と妥当性がより高い尺度へ洗練させることが課題で ある。 
謝辞：本研究の趣旨をご理解いただき, 快く協力いた だきました研究協力者の皆様抢よび研究協力施設の皆様 に心から感謝いたします。また本研究を遂行し論文をま とめるにあたり, 多くのご支援とご指導を賜りました小 松浩子教授に深く感謝申し上げます.

\section{文献}

1）日本透析医学会 : わが国の慢性透析療法の現況（2009 年 12 月 31 日現在)。透析会誌 $44: 1-36,2011$

2) 水口 潤 : 至適透析の概念と実際. 至適透析をめざし て：一歩すすんだ透析治療（太田和夫監修, 二瓶 宏, 佐中 孜編), p135-136, 中外医学社, 東京, 1997

3) Gurklis JA, Menke EM : Identification of stressors and use of coping methods in chronic hemodialysis patients. Nursing Research 37 : 236-239, 1988

4）正木治恵, 野口美和子, 滝本美佐子, 鳴海喜代子, 宮 本千津子, 山口覚太郎 : 慢性血液透析患者の透析ス卜 レッサーとコーピング行動について. 千葉大学看護学 部紀要 $12: 21-30,1990$

5）正木治恵，兼松百合子，小野ツル子，雨宮悦子，井部 俊子, 平野かよ子, 石原逸子, 志自岐康子, 中西睦子： 慢性病患者の療養のあり様に関する研究. 日看科会誌 $12: 1-9,1992$

6）鈴木美津枝, 阿部暢子, 奥田生久恵, 立花絵里, 村角 直子, 稲垣美智子, 桝田洋子：血液透析治療中患者の 生活の様相. 日腎不全看会誌 8：58-64, 2006

7) Bandura A : SELF-EFFICACY : The Exercise of Control. p3, WH Freeman and company, NewYork, 1997

8）祐宗省三, 原野広太郎, 柏木恵子, 春木 豊 : 社会的 学習理論の新展開. p35-45, 金子書房, 東京, 1985

9）高岸弘美：血液透析患者の自己管理に影響を及ぼす要 因とそれらの関連性に関する研究. 山梨県立大学看護 学部紀要 $10: 13-26,2008$

10）野崎智恵子, 布佐真理子：糖尿病性腎症を原疾患とす る血液透析患者の自己効力感とソーシャルサポート： 糖尿病患者の自己効力感との比較を通して. 東北大医 短部紀要 $11: 77-84,2002$

11）川端京子, 石田宣子, 岡美智代：血液透析患者の自己 管理行動および自己効力感に影響を及ぼす因子. 日生 理人類会誌 $3: 1-8,1998$

12）神谷千鶴, 今井雪香, 江川隆子 : 慢性血液透析患者の 健康行動に対するセルフエフィカシーの特徵. 日腎不 全看会誌 $2 ： 48-52,2000$

13）三島明子, 神谷千鶴, 今井雪香, 江川隆子：慢性血液 透析患者のセルフエフィカシーと自己管理の関係. 日 腎不全看会誌 $3: 56-62,2001$

14) Smith WR: Self-efficacy and compliance among hemodialysis patients. The master thesis, the Gradu- ate School of the University of Florida, 1988

15) Brady BA, Tucker CM, Alfino PA, Tarrant DG, Finlayson GC : An investigation of factors associated with fluid adherence among hemodialysis patients : a self-efficacy theory based approach. Ann Behav Med $19: 339-343,1997$

16) Lindberg $M$, Wikstrom $B$, Lindberg $P$ : Fluid Intake Appraisal Inventory : Development and psychometric evaluation of a situation-specific measure for haemodialysis patients' self-efficacy to low fluid intake. J Psychosom Res 63 : 167-173, 2007

17）金 外淑, 嶋田洋徳, 坂野雄二 : 慢性疾患患者の健康 行動に対するセルフ・エフィカシーとストレス反応と の関連. 心身医 36 : 499-505, 1996

18）岡美智代, 戸村成男, 宗像恒次, 土屋 滋 : 透析患者 の食事管理の自己効力尺度の開発. 日看会誌 5:4048, 1996

19）竹綱誠一郎, 鎌原雅彦, 沢崎俊之：自己効力に関する 研究の動向と問題. 教育心理学研究 $36: 172-184$, 1988

20）佐伯隆敏：腎臓病患者. 痛恨の記録一もっと早くよい 医者に出会えたら．現代書館，東京，1995

21）大坪公子：東京透析物語一よりよい透析ライフをめざ して. 日本医学出版, 東京, 1996

22）鈴木龍志：人工透析 10 年腎臓移植体験. $\mathrm{KK}$ ベスト セラーズ，東京，2001

23）中 義智：腎移植透析校長奮闘記. 三省堂, 東京, 1996

24）坂野雄二, 東條光彦 : 一般性セルフ・エフィカシー尺 度作成の試み. 行動療法研究 $12: 73-82,1986$

25）嶋田洋徳：一般性セルフエフィカシーの測定. セルフ エフィカシーの臨床心理学 (坂野雄二, 前田基成編), p50-52, 北大路書房, 京都, 2002

26）本明 寛, 野口京子：激動社会の中の自己効力. $\mathrm{p} 8$, 金子書房, 東京, 1997

27）島 悟：NIMH 原版準拠/CES-D Scale：うつ病（抑う つ状態)/自己評価尺度. 千葉テストセンター, 東京, 2001

28）矢冨直美, Liang Jersey, Krause Neal : CES-D による 日本老人のうつ症状の測定 : その因子構造における文 化差の検討. 社会老年学 $37: 37-47,1993$

29）鎌原雅彦：心理尺度の作成. 心理学マニュアル質問紙 法 (鎌原雅彦, 宮下一博編). p64-68, 北大路書房, 京 都, 2002

30）日本透析医学会 : わが国の慢性透析療法の現況（2000 年 12 月 31 日現在)。透析会誌 $35: 1-28,2002$

31） DF ポーリット, CT ベック著; 近藤潤子監訳 : 看護研 究原理と方法第 2 版. p435-437, 医学書院, 東京, 2010 